\title{
C-equivalent correction factor for soil organic carbon inventory by wet oxidation, dry combustion and loss on ignition methods in Himalayan region
}

\author{
Suresh Kumar $^{1, *_{\odot}}$, Yogesh Sopan Ghotekar ${ }^{1}$ and Vinay K Dadhwal ${ }^{2}$ \\ ${ }^{1}$ Indian Institute of Remote Sensing, ISRO, 4 Kalidas Road, Dehradun 248 001, India. \\ ${ }^{2}$ Indian Institute of Space Science and Technology, ISRO, Thiruvananthapuram, India. \\ *Corresponding author.e-mail: suresh_kumar@iirs.gov.in
}

MS received 7 April 2017; revised 23 February 2018; accepted 10 May 2018; published online 1 March 2019

Soil organic carbon (SOC) is an important parameter to study the carbon cycle as soil carbon stock inventory as well as to serve as prime indicator in assessing soil health and soil quality. The present study was attempted to investigate C-equivalent correction factor for SOC by Walkley-Black (wet oxidation) and loss on ignition (LOI) methods in relation to TOC analyzer (dry combustion) method. TOC analyzer method supposed to be the best method of total soil organic carbon estimation. Soil sample from 77 sites representing dominant land use/land cover types of crop land, forest and scrub cover were collected in Himalayan region of Uttarakhand state, India. Surface $(0-15 \mathrm{~cm})$ and sub-surface $(15-30 \mathrm{~cm})$ soil samples were used for estimation of SOC by these three methods. C-equivalent correction factor ranged from 1.10 to 1.17 for SOC determination by Walkley and Black method to TOC analyzer method, whereas it varied from 0.257 to 0.417 for soil organic matter (SOM) by LOI method to TOC analyzer for soils under various land use/land cover types in the Himalayan region. The recovery of SOC by WalkleyBlack method varied from 86.84 to $91.04 \%$ in the soils of various land use/land cover in the Himalayan landscape. Thus, there is need to develop specific correction factor for soils under various land use/land cover types for improved estimation of soil carbon stock. The regression models developed in the study can be directly used to obtain TOC analyzer equivalent total carbon contents in the soils (surface and sub-surface) for computation of soil carbon stock in Himalayan region.

Keywords. C-equivalent correction factor; TOC analyzer; LOI methods; soil organic carbon (SOC); Himalayan soils.

\section{Introduction}

Determination of soil carbon content is an important parameter to estimate soil carbon stock to study carbon cycle as well as in soil quality/health assessment for agriculture point of view. Physico-chemical composition of soil changes according to land uses (LUs) and management practices. Several researchers (Wang et al. 1996; Diaz-Zorita 1999; De Vos et al. 2007; Lettens et al. 2007; Gatto et al. 2009; Meersmans et al. 2009) showed that soil organic carbon (SOC) varies with land use/land cover types, at sampling depths and soil types in various climatic regions. Accumulation of organic matter, decomposition, nutrient recycling governs formation of different horizons 
influenced by soil under various land use/land cover types and their management practices. Ogle et al. (2003) and Goidts et al. (2009) reported large uncertainties in quantification of SOC stock that hamper reliable assessment. Several studies compared various analytical methods of soil carbon determination and their efficiency (Bisutti et al. 2004; Jankauskas et al. 2006). Among them, Walkley-Black, a wet oxidation method is widely used for estimation of SOC. It is simple, rapid and demands minimum equipment. But disposal of waste chemicals generated in the method is problematic and cost to environment. Recently, mid and near-infrared (MIR-NIR) spectroscopies have been found more precise in estimating soil organic carbon stock (Shepherd and Walsh 2002; Kaiser et al. 2007; Fontan et al. 2010). At Present, a dry combustion method is considered as the standard method due to its high precision and accuracy (Yeomans and Bremner 1988; Soon and Abboud 1991; Matejovic 1997) as compared to wet oxidation method. Walkley-Black method estimates only the most active organic carbon present in the soil (Nelson and Sommers 1996), leading to incomplete oxidation of organic matter (OM). This method had showed $74-77 \%$ recovery of soil organic carbon varies for various soils. SOC content obtained by Walkley-Black method in general underestimate the results obtained by dry combustion method (Mikhailova et al. 2003; Krishan et al. 2009) although a high correlation has been observed between these two methods (Jankauskas et al. 2006; Dieckow et al. 2007; Lettens et al. 2007; Meersmans et al. 2009). Loss on ignition (LOI) is another simple method used for determination of organic matter in the soil. It involves the heated destruction of all organic matter in the soil. It is based on estimating weight loss of soil by complete ignition of organic matter at high temperature of $450^{\circ} \mathrm{C}$ (Mitchell 1932; Davies 1974). The method may overestimate SOM due to evaporation of tightly bound water, decomposition of mineral compounds or may underestimate because of incomplete ignition.

Walkley-Black method is insensitive to identify small changes over time in response to land use changes and management practices (Florent et al. 2011). SOC estimated by Walkley-Black method has been compared with dry combustion based TOC analyzer method. To avoid the methodological biases, SOC content by wet oxidation was compared with dry combustion using C-equivalent correction factor (CF) of 1.3 (Walkley and Black 1934a, b). However, Mikhailova et al. (2003) reported C-equivalent $\mathrm{CF}$ of 1.63 for a Russian Chernozemic soil. Nelson and Sommers (1996) found C-equivalent ( $\mathrm{CF}$ ) factor ranging from 1.16 to 1.59 for range of soils, however, Dieckow et al. (2007) proposed a value of 1.05 for a subtropical soil in southern Brazil under different tillage and cropping systems. TOC content is the basis to calculate the SOM by applying conversion factor that is based on the content of carbon (C) in organic matter. On an average, SOM contains $58 \%$ of carbon content means conversion factor of 1.724 was made for conversion of TOC to SOM and is used globally (Walkley and Black 1934a, b). It is observed that content of carbon in SOM varies depending on biochemical composition of soil type and its decomposition state (Apolonia and Grazyna 2012).

It is well established that $60-80 \%$ SOC is only oxidized in Walkley-Black method. Therefore, a standard factor of 1.298 (assuming $77 \%$ recovery) is commonly used for conversion of SOC estimated by Walkley-Black method to total soil organic carbon (TOC). However, the actual recovery varies depend upon the nature of organic matter, site specificity and accuracy of method used for analysis. The present study aims to find out C-equivalent correction/conversion factors for (i) SOC based on Walkley-Black to TOC analyzer method and (ii) soil organic matter (SOM) based on LOI to TOC analyzer method for surface and sub-surface soils under various land use/land cover types in the Himalayan region, Uttarakhand state, India. C-equivalent factors for conversion of SOC based on Walkley-Black and SOM based on LOI method to TOC analyzer method, this conversion will help in improving the assessment of soil carbon stock and studying soil quality in the Himalayan region. The C-equivalent correction factor developed in the study will be quite useful in precise and improved estimation of SOC density and stock in absence of high end instrumentation like TOC analyzer and $\mathrm{CHN}$ analyzer.

\section{Materials and methods}

\subsection{Soil sampling}

Soil samples were collected from Himalayan mountainous landscape of the Uttarakhand state. These samples were collected from four transects namely (i) Chamba (Tehri Garhwal) to Uttarkashi, 
(ii) Rudraprayag to Badrinath, (iii) Kashipur to Almora and (iv) Rudrapur to Pithoragarh district in Uttarakhand state. Soil samples were collected from Himalayan landscape comprised of various forest types, croplands and scrub lands at two depths of $0-15 \mathrm{~cm}$ and $15-30 \mathrm{~cm}$ at different altitudes in the region. The elevation of soil sample sites ranged from 550 to 3220 meter above the mean sea level (MSL). The physiographic factors such as relief, slope and altitude are controlling factors of soil formation in the Himalayan region (Sidhu and Surya 2014). The landscape comprised of physiographic units of side slopes of hills, moderate sloping valley and undulating piedmont plains. Hills with steep to very steep side slope covered dominantly with forest and scrub cover, and bench terraces on moderately steep to steep sloping hills mostly under cultivation. Valley and piedmont area were mainly under cultivation. Pine (Pinus roxburghii), oak (Quercus spp.), banj oak (Quercus leucotrichophora), deodar (Cedrus deodara), and sal (Shorea robusta) were the dominant forest tree species found in the region. The common crops grown in the region were maize, paddy, wheat, potato, finger millets (mundua), barnyard millet (jhnagora) and french beans. Maize/ricewheat or coarse millets/rice-wheat based cropping is followed in the area. The terraced cropland are characterized with dominant slope of $20-40 \%$, whereas forest and scrub lands with slope of $50-80 \%$ in the region. The soils are dominantly sandy loam, loam/silt loam and silty clay loam containing 10-15, 14-26 and 28-35\% clay content, respectively, in these soil textures.

In the study, soil samples from 77 sites in the Himalayan region were collected that represented 22 sites in agriculture land, 41 in forest cover and 11 in scrub lands. These samples (total nos. 154) were processed and analyzed for SOC by WalkleyBlack method, LOI methods and TOC analyzer instrument.

\subsection{Analysis of soil carbon content in the soil}

\subsubsection{Walkley-Black (W-B) method}

Soil samples were grinded and passed through $0.2 \mathrm{~mm}$ sieve. Weigh $0.1-0.5 \mathrm{gm}$ of soil depending upon the general idea from soil color and the $\mathrm{C}$ concentration in soil and transfer to the $500 \mathrm{ml}$ volumetric flask of borosilicate glass. $10 \mathrm{ml}$ of $1 \mathrm{~N}$ potassium dichromate $\left(\mathrm{K}_{2} \mathrm{Cr}_{2} \mathrm{O}_{7}\right)$ and $20 \mathrm{ml}$ of concentrated sulphuric acid $\left(\mathrm{H}_{2} \mathrm{SO}_{4}\right)$ were added to soil and stir well to ensure the proper mixing. After $30 \mathrm{~min}, 200 \mathrm{ml}$ of distilled water and $10 \mathrm{ml}$ of concentrated orthophosphoric acid were added to the sample. Thereafter, $1 \mathrm{ml}$ of Diphenylamine indicator was added in flask and unconsumed potassium dichromate was determined by titration (back titration) with $0.5 \mathrm{~N}$ ammonium ferrous sulphate to determine SOC in the soil (Walkley and Black 1934a, b).

\subsubsection{Dry combustion method using TOC analyzer}

For determination of total organic carbon, total organic carbon (TOC) analyzer (Make-Shimadzu, Model-TOC VcpH along with solid sample moduleSSM-5000A), a high end instrument was used (Schumacher 2002; De Vos et al. 2007). TOC analyzer was calibrated using the sucrose and sodium carbonate as the total carbon (TC) and inorganic carbon (IC) standard. For measurement of TC, 50-100 $\mathrm{mg}$ of fine homogenized soil sample (0.2 $\mathrm{mm}$ mesh sieve passed) was weighed in a ceramic sample boat and was then transferred into a $900^{\circ} \mathrm{C}$ catalytic (mixture of cobalt oxide and platinum) combustion chamber, where soil carbon was oxidized into $\mathrm{CO}_{2}$ with aid of oxygen gas. The produced $\mathrm{CO}_{2}$ was carried by carrier gas $\left(\mathrm{O}_{2}\right)$ into the non-dispersive infrared (NDIR) detector and is detected or measured. For IC determination, weigh 50-100 mg of soil in a ceramic sample boat and then add $0.5 \mathrm{ml}$ of $85 \%$ phosphoric acid to the sample by using dispenser. Thereafter, sample boat was transferred into a $200^{\circ} \mathrm{C}$ combustion chamber to produce $\mathrm{CO}_{2}$ which was measured by NDIR detector. The difference between the TC and IC was taken as total organic carbon (Chua and Tokura 2004).

\subsubsection{Loss on ignition method (LOI)}

Per cent soil organic matter (SOM) was determined using LOI method (Mitchell 1932; Davies 1974). $2-5 \mathrm{gm}$ of soil sample (0.2 $\mathrm{mm}$ mesh sieve passed) was weighed in known weight of empty silica crucible. It was then heated in oven at $105^{\circ} \mathrm{C}$ for $24-36 \mathrm{hrs}$ to remove all of the moisture content then cooled the crucible in desiccators and weighed. This soil weight was taken as dry weight of soil and then transferred the silica crucibles into the muffle furnace at $450^{\circ} \mathrm{C}$ for $4 \mathrm{hrs}$. Thereafter, it was cooled in desiccators and weighed. The weight of soil loss expressed as a 
percentage of dry soil weight. LOI or per cent SOM was estimated as:

$$
\begin{aligned}
\operatorname{LOI}(\%)= & ((\text { Dry weight of soil } \\
& - \text { weight of soil after ignition }) \\
& / \text { dry weight of soil }) \times 100 .
\end{aligned}
$$

\section{Results and discussion}

\subsection{Soil organic carbon in soils of Himalayan landscape}

Soil samples representing various land use/land cover were analyzed for SOC by Walkley-Black (wet oxidation), TOC analyzer (dry combustion method) and SOM by LOI methods. The SOC content in the surface and sub-surface soil samples of various land use/land cover were summarized in table 1.

In crop land, mean SOC in the surface and sub-surface soils were estimated as 1.196 ( $\mathrm{SD} \pm$ $0.669)$ and 0.821 (SD \pm 0.524$)$ per cent, respectively by Walkley-Black (W-B) method and 1.363 $(\mathrm{SD} \pm 0.728)$ and $0.907(\mathrm{SD} \pm 0.564) \%$ by $\mathrm{TOC}$ analyzer method. Analysis revealed that W-B method had recovery of $86.84(\mathrm{SD} \pm 9.667)$ and 90.92 (SD \pm 9.293) per cent for surface and subsurface soils in comparison to total organic carbon by TOC analyzer method. In forest land, mean SOC in surface and sub-surface soils were estimated as $1.796(\mathrm{SD} \pm 0.903)$ and 0.936 ( $\mathrm{SD} \pm$ 0.637 ) per cent, respectively, by $\mathrm{W}-\mathrm{B}$ method and $2.049(\mathrm{SD} \pm 1.066)$ and $1.055(\mathrm{SD} \pm 0.730) \%$ by TOC analyzer method. The analysis revealed that W-B method had recovery of $88.53(\mathrm{SD} \pm 5)$ and $89.47(\mathrm{SD} \pm 7.896)$ per cent for surface and sub-surface soils in comparison to total organic carbon by TOC analyzer method for forest soils. In scrub land, mean SOC in surface and subsurface soils were estimated as $1.674(\mathrm{SD} \pm 0.821)$ and 0.748 ( $\mathrm{SD} \pm 0.540$ ) per cent, respectively, by $\mathrm{W}-\mathrm{B}$ method and $1.838(\mathrm{SD} \pm 0.923)$ and 0.828 ( $\mathrm{SD} \pm 0.610) \%$ by TOC analyzer method. It revealed that $\mathrm{W}-\mathrm{B}$ method had recovery of $91.04(\mathrm{SD} \pm 4.303)$ and $90.65(\mathrm{SD} \pm 7.319)$ per cent for surface and sub-surface soils in comparison to total organic carbon by TOC analyzer method. The study revealed that the SOC was underestimated by Walkley-Black method when it was compared with TOC analyzer method. The recovery of SOC by Walkley-Black method




was found highest of surface soils of scrub land (91.04\%) followed by forest land $(88.53 \%)$ and crop land $(86.84 \%)$. It might be due to easily oxidisable organic carbon present in the scrub land soil.

SOM was analyzed in surface and sub-surface soils using LOI method. In crop land, mean SOM in the surface and sub-surface soils were estimated of $4.019(\mathrm{SD} \pm 1.596)$ and $3.130(\mathrm{SD} \pm 1.232)$ per cent, respectively. In forest land, SOM was estimated as $5.497(\mathrm{SD} \pm 2.199), 3.843(\mathrm{SD} \pm 1.819) \%$ in the surface and sub-surface soils, respectively, and $4.802(\mathrm{SD} \pm 2.405)$ and $3.075(\mathrm{SD} \pm 1.568)$ per cent, respectively, in the scrub land. It showed that soils of the forest land are high in SOM followed by scrub land and crop land.

\subsection{Correction factor (CF) for soil organic carbon (SOC) by Walkley-Black $(W-B)$ method}

$\mathrm{W}-\mathrm{B}$ method is used to estimate available organic carbon in the soil. The available SOC is converted to TOC by multiplying the standard correction factor of 1.298 (assuming recovery $77 \%$ by $\mathrm{W}-\mathrm{B}$ method). It has been observed that the recovery of SOC $(77 \%)$ varies in the soils under various land use/land cover ( $\mathrm{LU} / \mathrm{LC})$. The recovery of SOC also varies in surface and sub-surface soils (Leighty and Shorey 1930; Lunt 1931; Broadbent 1953). In the study, SOC estimated with TOC analyzer method was compared with $\mathrm{W}-\mathrm{B}$ method with applying standard correction factor 1.298. It had been observed that SOC was overestimated with the standard CF 1.298, whereas underestimated without applying CF (figure 1). The analysis revealed that recovery of SOC by Walkley-Black method varies from $86-91 \%$ for the soils of Himalayan region under various $\mathrm{LU} / \mathrm{LC}$. Thus, it implied that single CF of 1.298 cannot be used for all soils of surface and sub-surface of various LU/LC. Thus, there is need to derive $\mathrm{CF}$ for surface and sub-surface soils of various $\mathrm{LU} / \mathrm{LC}$.

\subsection{Relationship between SOC estimated by $W-B$ method and TOC analyzer}

Pearson regression analysis between soil organic carbon estimated by $\mathrm{W}-\mathrm{B}$ and TOC analyzer methods were attempted to establish relationship for soils of dominant land use/land cover types of the Himalayan landscape. Linear regression models were developed to estimate TOC from SOC estimated based on $\mathrm{W}-\mathrm{B}$ method for surface and sub-surface soils of crop, forest and scrub lands. A very high correlation of SOC by $\mathrm{W}-\mathrm{B}$ method (without applying correction factor 1.298) and TOC analyzer was found for surface soil $\left(R^{2}=0.98\right)$ and for sub-surface soil $\left(R^{2}=0.97\right)$ for crop land. Similarly, a significantly high correlation was found for surface $\left(R^{2}=0.99\right)$ and sub-surface soils $\left(R^{2}=0.99\right)$ of forest land and for surface $\left(R^{2}=\right.$ $0.99)$ and sub-surface soils $\left(R^{2}=0.99\right)$ of scrub land (table 2).

To avoid the methodological biases various researchers suggested different correction factors CFs for various soil types developed in various climatic condition. Walkley and Black (1934a,b) suggested a site-specific C-equivalent CF of 1.298, whereas Mikhailova et al. (2003) reported Cequivalent $\mathrm{CF}$ of 1.63 for a Russian Chernozemic soil. Nelson and Sommers (1996) obtained Cequivalent $\mathrm{CF}$ ranging from 1.16 to 1.59 for range of soils and Dieckow et al. (2007) proposed a value of 1.05 for a subtropical soil in southern Brazil under different tillage and cropping systems. The present study showed that, Walkley-Black method overestimated the SOC when standard CF of 1.298 was used. The ratio TOC by TOC analyzer to SOC by Walkley-Black method (TOC/SOC ${ }_{\mathrm{WB}}$ ) provide the correction factor for $\mathrm{SOC}_{\mathrm{WB}}$ to TOC method. A CF of 1.171 for surface and 1.114 for sub-surface soils for crop land whereas CF of 1.133 and 1.128 for surface and sub-surface soils of forest land were estimated. For scrub land soils, CF was estimated as 1.100 for surface and 1.111 for sub-surface soils (table 3 ). The regression equations were developed to convert SOC by Walkley-Black method to TOC for surface and sub-surface soils of crop land, forest and scrub land are given in table 2. These developed equations will help the researcher for precise estimation of TOC present in the soils of Himalayan landscape under dominant land use/land cover types.

Soil organic matter (SOM) composed of various non-lignin and lignin types of compounds. The composition of these compounds in SOM depends on the kind of residue added to the soils from various land use/land cover and vegetation types, degree of decomposition and soil forming processes. Lignin is relatively resistant to decomposition as compared to other biochemical compounds present in the soils. Baker (1936) described that soils containing easily decomposable non-lignin fractions in SOM had $100 \%$ recovery by $\mathrm{W}-\mathrm{B}$ method whereas low recovery $(76 \%)$ in soils containing SOM with lignin and lignin like material. Lettens et al. (2007) 


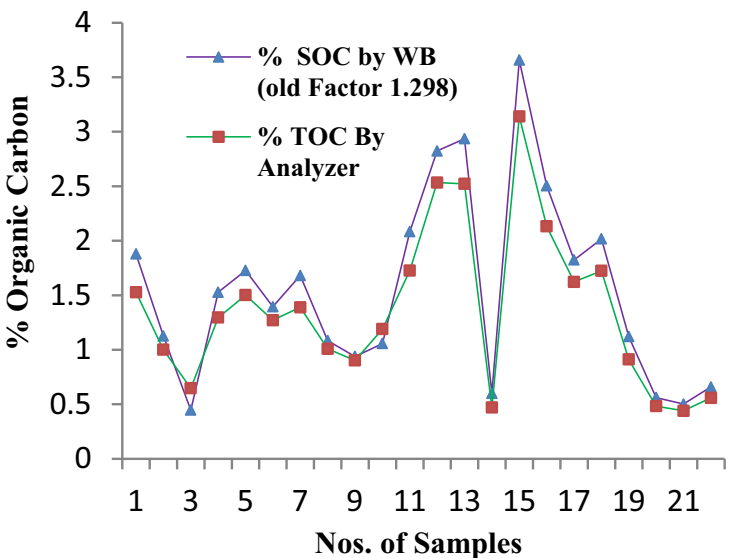

(a)

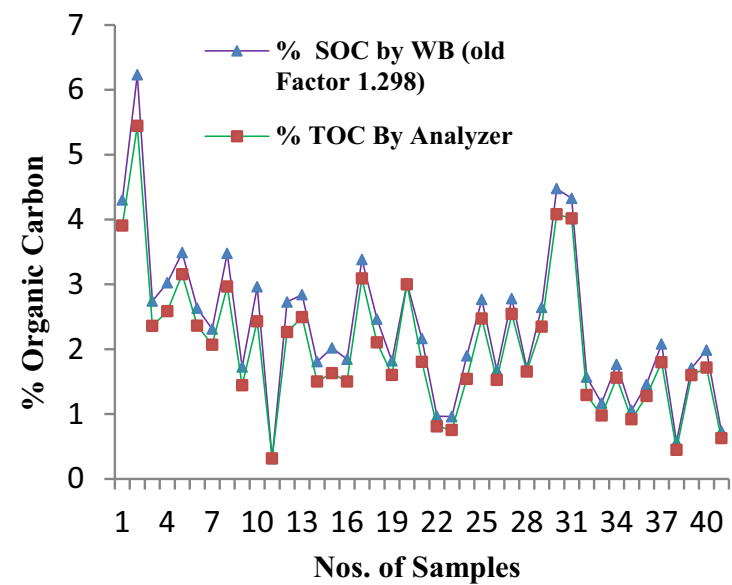

(c)

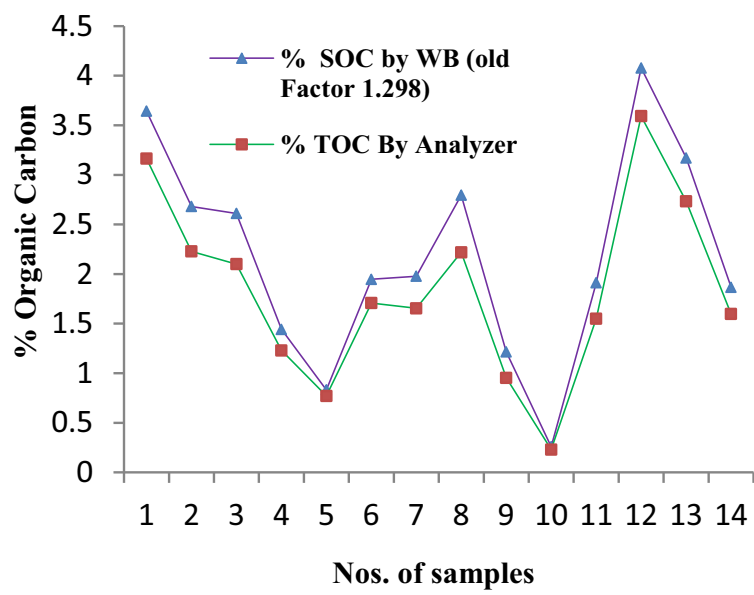

(e)

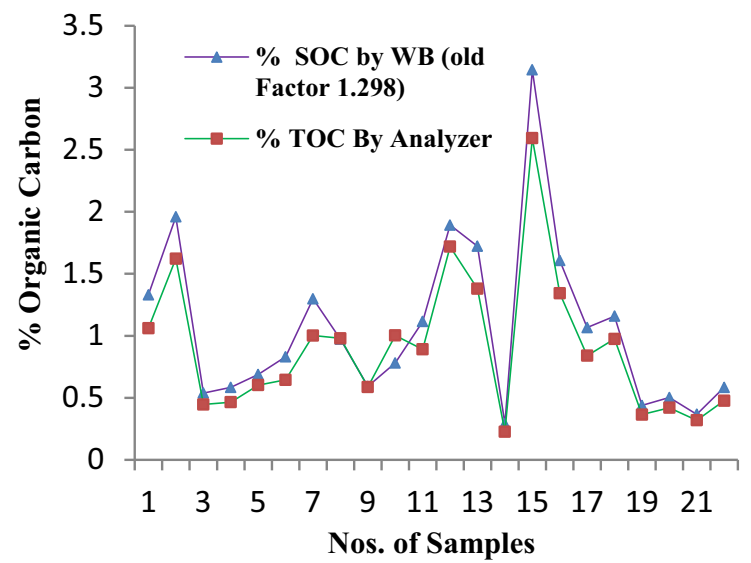

(b)

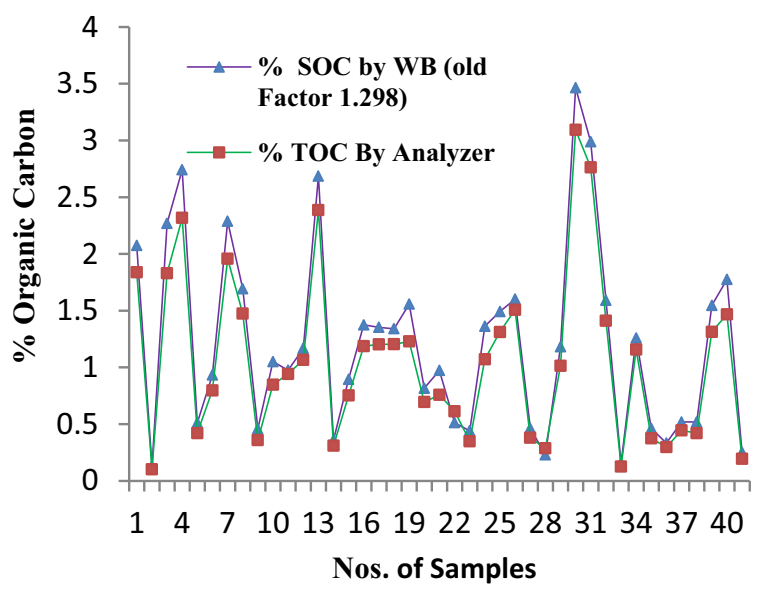

(d)

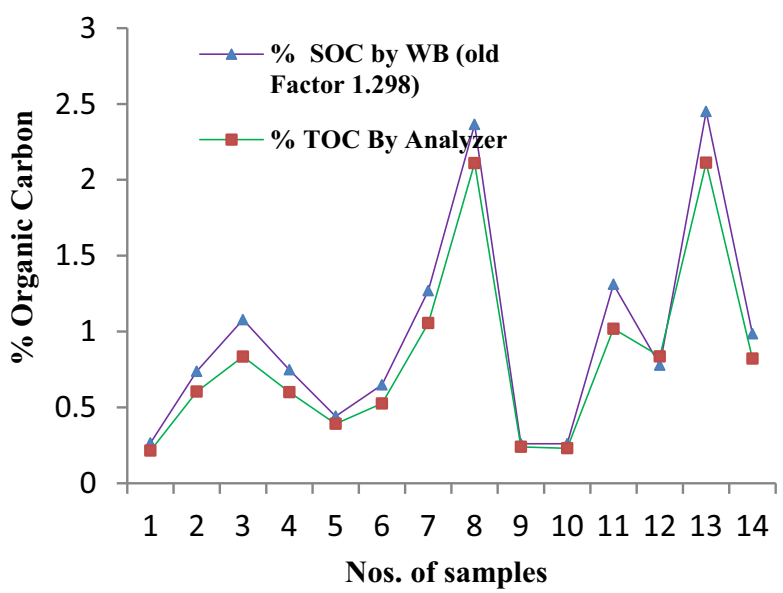

(f)

Figure 1. Graphical representation of analytical methods for SOC determined by W-B method with correction factor (1.298) and TOC by CHN analyzer (a) agriculture land (surface), (b) agriculture land (sub-surface), (c) forest land (surface), (d) forest land (sub-surface layer), (e) scrub land (surface), and (f) scrub land (sub-surface).

studied influence of land use on recovery of $\mathrm{W}-\mathrm{B}$ method in relation to TOC analyser and showed least recovery for forest soil $(61 \%)$ and higher for cropland (66\%). Similarly, Diaz-Zorita (1999) reported less recovery in pasture than the cultivation systems. It was explained that due to presence of lignin compound present in organic matter under pasture land that resist oxidation in the W-B method. De Vos et al. (2007) reported variable recovery rate of $\mathrm{SOC}$ rates for various 
Table 2. Linear regression equations between TOC and SOC (determined by $W$-B method) without applying correction factor.

\begin{tabular}{lcc}
\hline LULC (no. of samples) & Surface soil $(0-15 \mathrm{~cm})$ & Sub-surface soil $(15-30 \mathrm{~cm})$ \\
\hline Agriculture land $(n=22)$ & TOC $=1.0802 * \mathrm{OC}_{\mathrm{WB}}+0.0716$ & TOC $=1.0608 * \mathrm{OC}_{\mathrm{WB}}+0.0356$ \\
& $R^{2}=0.9844$ & $R^{2}=0.9712$ \\
Forest land $(n=41)$ & $\mathrm{TOC}=1.1766 * \mathrm{OC}_{\mathrm{WB}}-0.0648$ & TOC $=1.1405 * \mathrm{OC} \mathrm{WB}-0.0117$ \\
& $R^{2}=0.9911$ & $R^{2}=0.9914$ \\
Scrub land $(n=14)$ & TOC $=1.1193 * \mathrm{OC}_{\mathrm{WB}}-0.0363$ & TOC $=1.124 * \mathrm{OC} \mathrm{WB}-0.013$ \\
& $R^{2}=0.9928$ & $R^{2}=0.9877$
\end{tabular}

Table 3. TOC equivalent correction factor for SOC by $W-B$ and SOM by LOI method.

\begin{tabular}{|c|c|c|c|c|}
\hline \multirow{2}{*}{$\begin{array}{l}\text { Land use/land cover } \\
\text { (no. of samples) }\end{array}$} & \multicolumn{2}{|c|}{$\begin{array}{c}\text { Correction factor of SOC by W-B method } \\
\text { equivalent to TOC }\end{array}$} & \multicolumn{2}{|c|}{$\begin{array}{c}\text { Correction factor of SOM by LOI method } \\
\text { equivalent to TOC }\end{array}$} \\
\hline & Surface $(0-15 \mathrm{~cm})$ & Sub-surface $(15-30 \mathrm{~cm})$ & Surface $(0-15 \mathrm{~cm})$ & Sub-surface $(15-30 \mathrm{~cm})$ \\
\hline $\begin{array}{l}\text { Agriculture land } \\
(n=22)\end{array}$ & $1.171 \pm 0.182$ & $1.114 \pm 0.147$ & $0.329 \pm 0.064$ & $0.278 \pm 0.081$ \\
\hline Forest land $(n=41)$ & $1.133 \pm 0.066$ & $1.128 \pm 0.122$ & $0.360 \pm 0.075$ & $0.258 \pm 0.099$ \\
\hline Scrub land $(n=14)$ & $1.100 \pm 0.052$ & $1.111 \pm 0.100$ & $0.417 \pm 0.282$ & $0.257 \pm 0.097$ \\
\hline
\end{tabular}

forest soils. Forest soils showed recovery attributed to charcoal and resistant elementary carbon particles. However, they found a good linear relationship with TOC and W-B method. Pe'rez et al. (2001) summarized coefficients of variation determined by several authors in the analysis of OC by the Walkley and Black (1934a, b) method and a dry combustion method.

Bhattacharyya et al. (2015) suggested W-B recovery factors for Indian soils of different bioclimates and soil depth. Krishan et al. (2009) reported that the $\mathrm{W}-\mathrm{B}$ method underestimates SOC in Himalayan and Central Indian soils. They showed underestimation with an average of $45 \%$ for Himalayan soils and $33 \%$ for Central Indian soils. Lower recovery in the soils may be attributed to incomplete oxidation of organic carbon by $\mathrm{W}-\mathrm{B}$ method.

\subsection{Relationship between TOC and SOM estimated by LOI method}

Soil organic matter (SOM) was estimated of surface and sub-surface soil of crop, forest and scrub lands. The total organic carbon estimated (TOC analyzer) was divided by SOM estimated by LOI method (TOC/SOM by LOI) to obtain C-equivalent value (correction factor) for LOI method. A conversion factor of 1.724 (assuming $58 \% \mathrm{C}$ present in soil organic matter). This factor also refers as 'Van Bemmelen factor'. This factor is generally used to convert TOC to SOM, but it is also site specific as it depends on the nature, decomposition state of organic matter, soil forming processes and total carbon content of the organic matter. It is still study of interest to analyze effect of composition of SOM on the $\mathrm{C}$ content. Precise quantification of carbon present in various fraction of SOM is needed for determination of precise conversion factor of TOC to SOM and vice versa. A decrease in the $\mathrm{C}$ content of SOM in the deeper soil profile has been reported by several researchers (Jain et al. 1997; Varvel et al. 2002; Chabbi et al. 2009). A very good correlation of SOM by LOI method and TOC analyzer was found for surface soil $\left(R^{2}=0.85\right)$ and for sub-surface soil $\left(R^{2}=0.76\right)$ for crop land. Similarly, a significantly high correlation was found for surface soil $\left(R^{2}=0.89\right)$ and sub-surface soil $\left(R^{2}=0.76\right)$ for forest soil and for surface $\left(R^{2}=0.70\right)$ and sub-surface $\left(R^{2}=0.73\right)$ soils of scrub land (figure 2).

A CF of 0.329 for surface and 0.278 for subsurface soils of crop land was obtained whereas 0.36 and 0.258 for surface and sub-surface soils of forest land were estimated. For scrub land soils, CF was estimated of 0.417 for surface and 0.257 for sub-surface soils (table 3 ). The regression equations were developed to convert SOM by LOI method to TOC for surface and sub-surface soils of crop land, forest and scrub land are given in table 4 . The developed equations will be quite useful in precise estimation of TOC present in the 


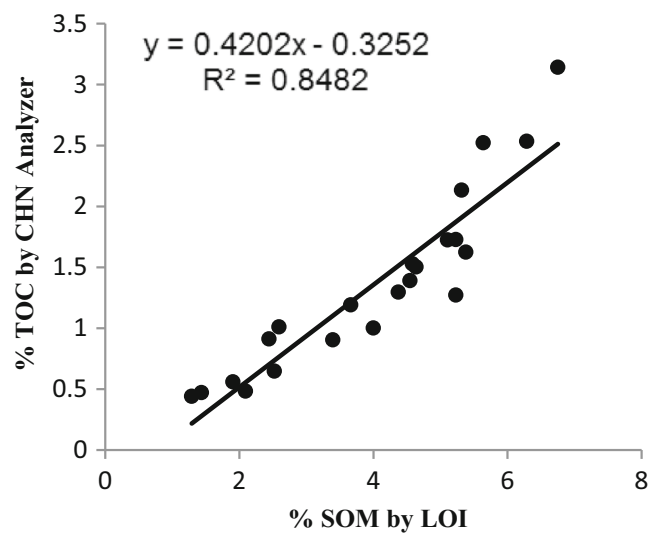

(a)

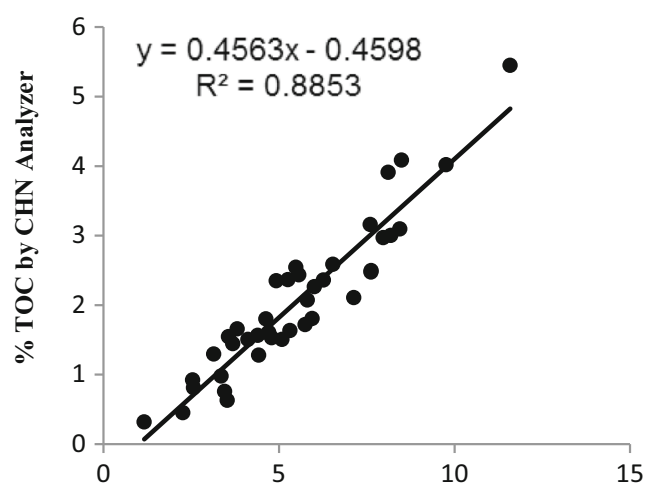

(c)

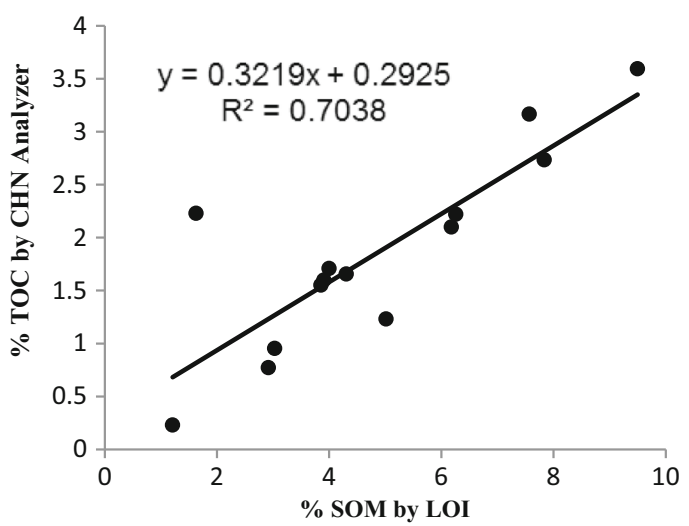

(e)

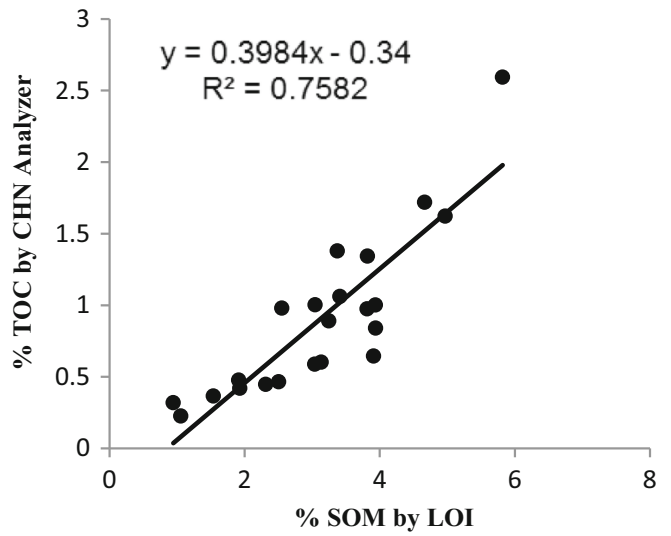

(b)

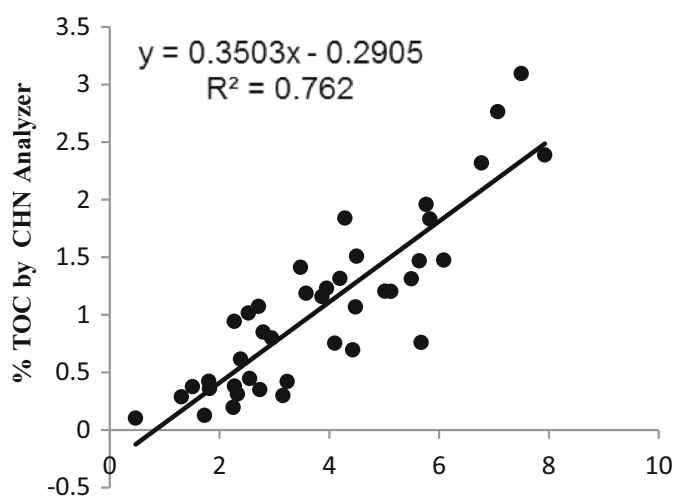

(d)

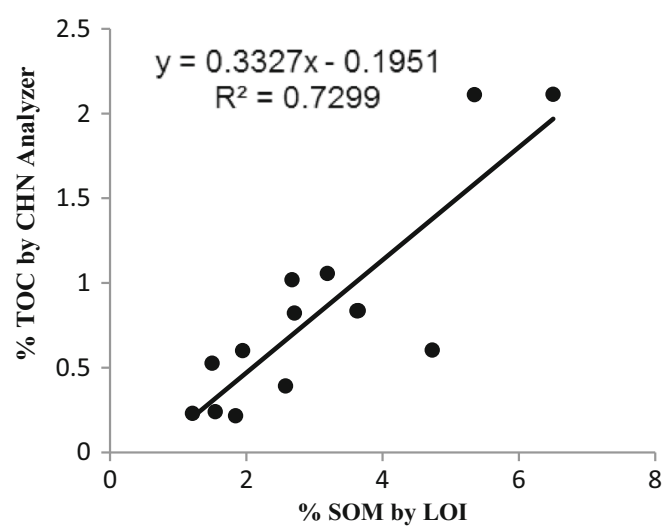

(f)

Figure 2. Pearson correlation of soil TOC with SOM estimated by LOI method for (a) agriculture land (surface), (b) agriculture land (sub-surface), (c) forest land (surface), (d) forest land (sub-surface), (e) scrub land (surface), and (f) scrub land (sub-surface).

Table 4. Linear regression equations between TOC and SOM estimated by LOI method.

\begin{tabular}{lcc}
\hline LULC (no. of samples) & Surface soil $(0-15 \mathrm{~cm})$ & Sub-surface soil $(15-30 \mathrm{~cm})$ \\
\hline Agriculture land $(n=22)$ & TOC $=0.4202 *$ SOM by LOI -0.3252 & TOC $=0.3984 *$ SOM by LOI -0.34 \\
& $R^{2}=0.8482$ & $R^{2}=0.7582$ \\
Forest land $(n=41)$ & TOC $=0.4563 *$ SOM by LOI -0.4598 & TOC $=0.3503 *$ SOM by LOI -0.2905 \\
& $R^{2}=0.8853$ & $R^{2}=0.762$ \\
Scrub land $(n=14)$ & TOC $=0.3219 *$ SOM by LOI +0.2925 & TOC $=0.3327 *$ SOM by LOI -0.1951 \\
& $R^{2}=0.7038$ & $R^{2}=0.7299$
\end{tabular}


soils of Himalayan landscape under dominant land use/land cover types.

\section{Conclusions}

Study revealed that Walkley-Black (W-B) method underestimated the total soil organic carbon (SOC) in the surface and sub-surface soils under various land use/land cover in the Himalayan landscape. Recovery of SOC estimated by $\mathrm{W}-\mathrm{B}$ method varies in the soils of various land use/land cover. It may be attributed to the physiography, parent material, land use/land cover and climatic conditions, thus there is strong need to develop appropriate correction factor (CF) for soils under various land use/land cover types to assess precise soil carbon stock in a region. Several studies have assessed SOC stock based on soil carbon determined by $\mathrm{W}-\mathrm{B}$ method. Improved and reliable soil carbon stock assessment method necessitated to use TOC analyzer method but due to non-availability of it to the researcher has resulted in underestimation of SOC stock.

Conversion factors $(\mathrm{CF})$ for SOC estimated by Walkley-Black method to total organic carbon equivalent to result of TOC analyzer instrument were estimated as 1.171 and 1.114 for soils of crop lands in surface and sub-surface soils, respectively, and 1.133 and 1.128 for soils of forest land in surface and sub-surface soils, respectively. For soils of scrub land, CF of 1.10 and 1.11 for surface and sub-surface were obtained. Similarly, correction factors for SOM by LOI method to TOC were estimated as 0.329 for surface, 0.278 for sub-surface soils for crop land; 0.360 and 0.258 for surface and sub-surface soils of forest land and 0.417 and 0.257 for surface and sub-surface soils for scrub land in the Himalayan landscape.

The present study will help to the researchers/ planners for reliable and precise assessment of soil carbon stock and soil quality in case of nonavailability of high end instrumentation like TOC analyzer. They can precisely estimate the total organic carbon using simple methods of LOI or Walkley-Black methods. An improved estimation of SOC stock can be obtained using the correction factors of previous studies carried out using Walkley-Black method. The correction factors derived in the study can be used for improved estimation of soil carbon stock in the soils of Himalayan landscape.

\section{Acknowledgements}

Authors are sincerely grateful for financial support provided under the ISRO-Geosphere Biosphere Program (IGBP) of the Department of Space. Authors sincerely thank Director, Indian Institute of Remote Sensing (IIRS) and Director, National Remote Sensing Centre (NRSC), Hyderabad, for their kind support and constant encouragement.

\section{References}

Allison L E 1960 Wet-combustion apparatus and procedure for organic and inorganic carbon in soil; Soil Sci. Soc. Am. Proc. 24 36-40.

Apolonia O and Grazyna P 2012 Assessment of TOC-SOM and SOM-TOC conversion in forest soil; Pol. J. Environ. Stud. 21 1767-1775.

Baker G O 1936 A study of the practicability of the WalkleyBlack method for determining soil organic matter; Soil Sci. 41 47-51.

Bhattacharyya T, Chandran P, Ray S K, Mandal C, Tiwary P, Pal D K, Maurya U K, Nimkar A M, Kuchankar H, Sheikh S, Telpande B A and Kolhe A 2015 WalkleyBlack recovery factor to reassess soil organic matter: Indo-Gangetic plains and black soil region of India case studies; Commun. Soil Sci. Plant Anal. 46 2628-2648.

Bisutti I, Hilke I and Raessler M 2004 Determination of total organic carbon - An overview of current methods; Trends Analyst. Chem. 23 716-726.

Broadbent F E 1953 The soil organic fraction; Adv. Agron. 5 153-183.

Chabbi A, Kogel-Knabner L and Rumpel C 2009 Stabilized carbon in subsoil horizon is located in spatially distinct parts of soil profile; Soil Biol. Biochem. 41256.

Chua A M and Tokura T 2004 Total organic carbon in soil; Shimadzu Application news, May 2004.

Davies B E 1974 Loss-on-Ignition as an estimate of soil organic matter; Soil Sci. Soc. Am. Proc. 38 150-151.

De Vos B, Lettens S, Muys B and Deckers J A 2007 WalkleyBlack analysis of forest soil organic carbon, limitations and uncertainty; Soil Use Manag. 23 221-229.

Diaz-Zorita M 1999 Soil organic carbon recovery by the Walkley-Black method in a Typic Hapludoll; Commun. Soil Sci. Plant Anal. 30 739-745.

Dieckow J, Mielniczuk J, Knicker H, Bayer C, Dick D P and Kogel-Knaber I 2007 Comparison of carbon and nitrogen determination methods for samples of a peleudult subjected to no-till cropping systems; Sci. Agric. 64 532-540.

Florent T, Joao Carlos de Moraes Sa, Paulo R B, Philippe L, Clever B, Ademir O F, Josiane B dos Santos and Thiago Massao Inagaki 2011 Soil carbon inventory by wet oxidation and dry combustion methods: Effect of land use, soil texture, gradients and sampling depth on linear model of C-equivalent correction factor; Soil Sci. Soc. Am. J. $\mathbf{7 6}$ 1048-1059.

Fontan J M, Calvache S, Lopez-Bellido R J and LopezBellido L 2010 Soil carbon measurement in clods and sieved sample in a Mediterranean Vertisol by visible nearinfrared reflectance spectroscopy; Geoderma 156 93-98. 
Gatto A, Barros N F, Novais R F, Silva I R, Mendonca E D and Vaillani E M D 2009 Comparison of methods for determination of organic carbon in soils under eucalypt plantation; Rev. Bras. Cienc. Solo. 33 735-740.

Goidts E, Wesemael B and Crucifix M 2009 Magnitude and sources of uncertainties in soil organic carbon (SOC) stock assessment at various scales; Eur. J. Soil. Sci. 60 723-739.

Jain T B, Graham R T and Adams D L 1997 Carbon to organic matter ratios for soil in rocky Mountain coniferous forests; Soil Sci. Soc. Am. J. 611190.

Jankauskas B, Slepetience A, Jankauskiene G, Fullen M A and Booth C A 2006 A comparative study of analytical methodologies to determine the soil organic matter content of Lithuanian Eutric Albeluvisols; Geoderma 136 763-773.

Kaiser M, Ellerbrock R H and Gerke H H 2007 Long-term effects of crop rotation and fertilization on soil organic matter composition; Eur. J. Soil Sci. 58 1460-1470.

Krishan G, Srivastav S K, Kumar S, Saha S K and Dadhwal V K 2009 Quantifying the underestimation of soil organic carbon by Walkley and Black technique-examples from Himalayan and Central Indian Soils; Curr. Sci. 96(8) 1133-1136.

Leighty W R and Shorey E C 1930 Some carbon-nitrogen relations in soils; Soil Sci. 30 257-266.

Lettens S, Vos B D, Quataert P, Wesemael B, Muys B and Orshoven J 2007 Variable carbon recovery of WalkleyBlack analysis and implication of national soil organic accounting; Eur. J. Soil Sci. 58 1244-1253.

Lunt H A 1931 The carbon-organic matter factor in forest soil humus; Soil Sci. 32 27-33.

Matejovic I 1997 Determination of carbon and nitrogen in samples of various soils by the dry combustion; Commun. Soil Sci. Plant Anal. 28 1499-1511.

Meersmans J, Wesemael B V and Molle M V 2009 Determining soil organic carbon for agriculture soils: Comparison between the Walkley and Black and dry combustion methods (north Belgium); Soil Use Manag. 25 346-353.

Mikhailova E A, Nobel R R P and Post C J 2003 Comparison of soil organic carbon recovery by Walkely-Black and dry combustion methods in the Russian Chernozein; Commun. Soil Sci. Plant Anal. 34 1853-1860.

Mitchell J 1932 The origin, nature, and importance of soil organic constituents having base exchange properties; J. Am. Soc. Agron. 24 256-275.

Corresponding editor: NAVIN JUYAL
Nelson W and Sommers L E 1996 Total carbon, organic carbon and organic matter. In: Method of soil analysis. Part 3: Chemical methods (ed.) Sparks D L, SSSA Book Ser. 5. SSSA, Madison, WI, pp. 961-1010.

Ogle S M, Breidt F J, Eve M D and Paustian K 2003 Uncertainty in estimating land use and management impacts on soil organic carbon storage for US agriculture lands between 1982 and 1997; Gobal Change Biol. 9 1521-1542.

Pe'rez D V, de Alcantara S, Arruda R J and Amaral Meneghelli N 2001 Comparing two methods for soil carbon and nitrogen determination using selected Brazilian soils; Commun. Soil Sci. Plant Anal. 32 295-309.

Schumacher B A 2002 Methods for the determination of total organic carbon (TOC) in soils and sediments, Ecological Risk Assessment Support Center, US EPA.

Shepherd K D and Walsh M G 2002 Development of reflectance spectral libraries for characterization of soil properties; Soil Sci. Soc. Am. J. 66 988-998.

Sidhu G S and Surya J N 2014 Soils of North-Western Himalayan eco-system and their land use constraints, productivity potentials and future strategies; Agropedology 24(01) 1-19.

Soon Y K and Abboud S 1991 A comparison of some methods for soil organic carbon determination; Commun. Soil Sci. Plant Anal. 30 2299-2310.

Varvel G E, Liebig M A and Doran J W 2002 Soil Organic Matter Assessments in a long term cropping system study; Commun. Soil Sci. Plant Anal. 33 2119-2130.

Walkley A and Black I A 1934a An examination of Degtjareff method for determining organic carbon in soils: Effect of variations in digestion conditions and of inorganic soil constituents; Soil Sci. 63 251-263.

Walkley A and Black I A 1934b An examination of the Degtjareff method for determining soil organic matter, and a proposed modification of the chromic acid titration method; Soil Sci. 37 29-38.

Wang X J, Smethurst P J and Herbert A M 1996 Relationship between three measures of organic matter or carbon in soils of eucalypt plantation in Tasmania; Aust. J. Soil Res. 34 545-553.

Yeomans J C and Bremner J M 1988 A rapid and precise method for routine determination of organic carbon in soil; Commun. Soil Sci. Plant Anal. 191467. 